\title{
REVISIONS AND EXTENSION OF THE HOHENHEIM OAK AND PINE CHRONOLOGIES: NEW EVIDENCE ABOUT THE TIMING OF THE YOUNGER DRYAS/PREBOREAL TRANSITION
}

\author{
MARCO SPURK, ${ }^{1}$ MICHAEL FRIEDRICH, ${ }^{1}$ JUTTA HOFMANN,${ }^{l}$ SABINE REMMELE, ${ }^{1}$ \\ BURKHARD FRENZEL, ${ }^{1}$ HANNS HUBERT LEUSCHNER ${ }^{2}$ and BERND KROMER ${ }^{3}$
}

\begin{abstract}
Oak and pine samples housed at the Institute of Botany, University of Hohenheim, are the backbone of the early Holocene part of the radiocarbon calibration curve, published in 1993 (Becker 1993; Kromer and Becker 1993; Stuiver and Becker 1993; Vogel et al. 1993). Since then the chronologies have been revised. The revisions include 1) the discovery of 41 missing years in the oak chronology and 2) a shift of $54 \mathrm{yr}$ for the oldest part back into the past. The oak chronology was also extended with new samples as far back as $10,429 \mathrm{BP}(8480 \mathrm{BC})$. In addition, the formerly tentatively dated pine chronology (Becker 1993) has been rebuilt and shifted to an earlier date. It is now positioned by ${ }^{14} \mathrm{C}$ matching at $11,871-9900 \mathrm{BP}(9922-$ 7951 BC) with an uncertainty of $\pm 20 \mathrm{yr}$ (Kromer and Spurk 1998). With these new chronologies the ${ }^{14} \mathrm{C}$ calibration curve can now be corrected, eliminating the discrepancy in the dating of the Younger Dryas/Preboreal transition between the proxy data of the GRIP and GISP ice cores (Johnsen et al. 1992; Taylor et al. 1993), the varve chronology of Lake Gościąż (Goslar et al. 1995) and the pine chronology (Becker, Kromer and Trimborn 1991).
\end{abstract}

\section{INTRODUCTION}

After Bernd Becker's death in February 1994, we tried to close the so-called "Hallstatt gap", which was a gap in Hohenheim chronology as it existed in 1993. To accomplish this, the authors at Hohenheim checked the correctness of each single sample of the Hohenheim chronology, using modern methods to check their dating. If there was reason to doubt the correctness of the ring-width pattern originally measured, the samples were measured anew. This task was supplemented by an identification of trees with growth disturbances caused by insect damage; such trees were excluded from the chronology. This triple check, and a comparison with the Göttingen oak chronology, confirmed Becker's work for the most part but also located two weak points in the oak chronology, and one in the Preboreal pine chronology. These minor revisions in the two long Hohenheim chronologies, and the collection of new samples that enabled the backwards extension of the oak chronology by almost $500 \mathrm{yr}$, resulted in a new link to the Preboreal pine chronology. Both the extension and the revisions are explained in this paper.

\section{COMPARISON OF HOHENHEIM AND GÖTTINGEN CHRONOLOGIES: THE 41-YR SHIFT AT 5242 BC}

The two South German oak chronologies from Hohenheim and Göttingen were constructed based on wood collected during the last 30 years (Leuschner 1992; Becker 1993). Most of the wood for both chronologies comes from gravel in the bed of the Main River, near the Franconian town of Bamberg. The chronologies were established independently of one another in most parts. A comparison of both chronologies revealed a 41-yr offset in the pre-5242 BC part. Detailed investigations showed that these 41 years were missing between 5242 and $5283 \mathrm{BC}(7191 \text { and } 7232 \mathrm{BP})^{4}$ from the Hohenheim chronology as published in 1993. The difficulty was caused by two samples labeled Sand 29 and Sand 33, which had been measured erroneously. After renewed measurements of these samples and the reestablishment of the pre-5100 BC section independently from the Göttingen chronology, formerly undated tree sections covering the missing years were located and inserted into the

\footnotetext{
'University of Hohenheim, Institute of Botany, D-70593 Stuttgart, Germany

${ }^{2}$ University of Göttingen, Albrecht-v.-Haller-Institute for Plant Sciences, D-37075 Göttingen, Germany

${ }^{3}$ Heidelberg Academy of Sciences, Institute of Environmental Physics, INF 366, D-69120 Heidelberg, Germany

${ }^{4}$ Conversion from $\mathrm{BC}$-age to $\mathrm{BP}$-age: $\mathrm{BP}-\mathrm{age}=\mathrm{BC}$-age $+1950-1$. (The 1 must be subtracted due to the lack of the year zero in the $\mathrm{BC}$ time scale.) All BP ages in this paper represent real calendar years unless otherwise indicated.
} 
Hohenheim chronology. This resulted in a perfect ring-width synchronization of the Hohenheim to the Göttingen oak chronologies back to the end of the absolute Göttingen chronology at $7197 \mathrm{BC}$ (9147 BP) (Leuschner 1992) (Fig. 1). The pre-7197 BC part of the Hohenheim chronology also displays perfect synchronization to a 578-yr-long floating sequence in the Göttingen chronology. Both long oak chronologies from Germany are now, for the first time, mutually corroborative back to 7736 BC (9685 BP).

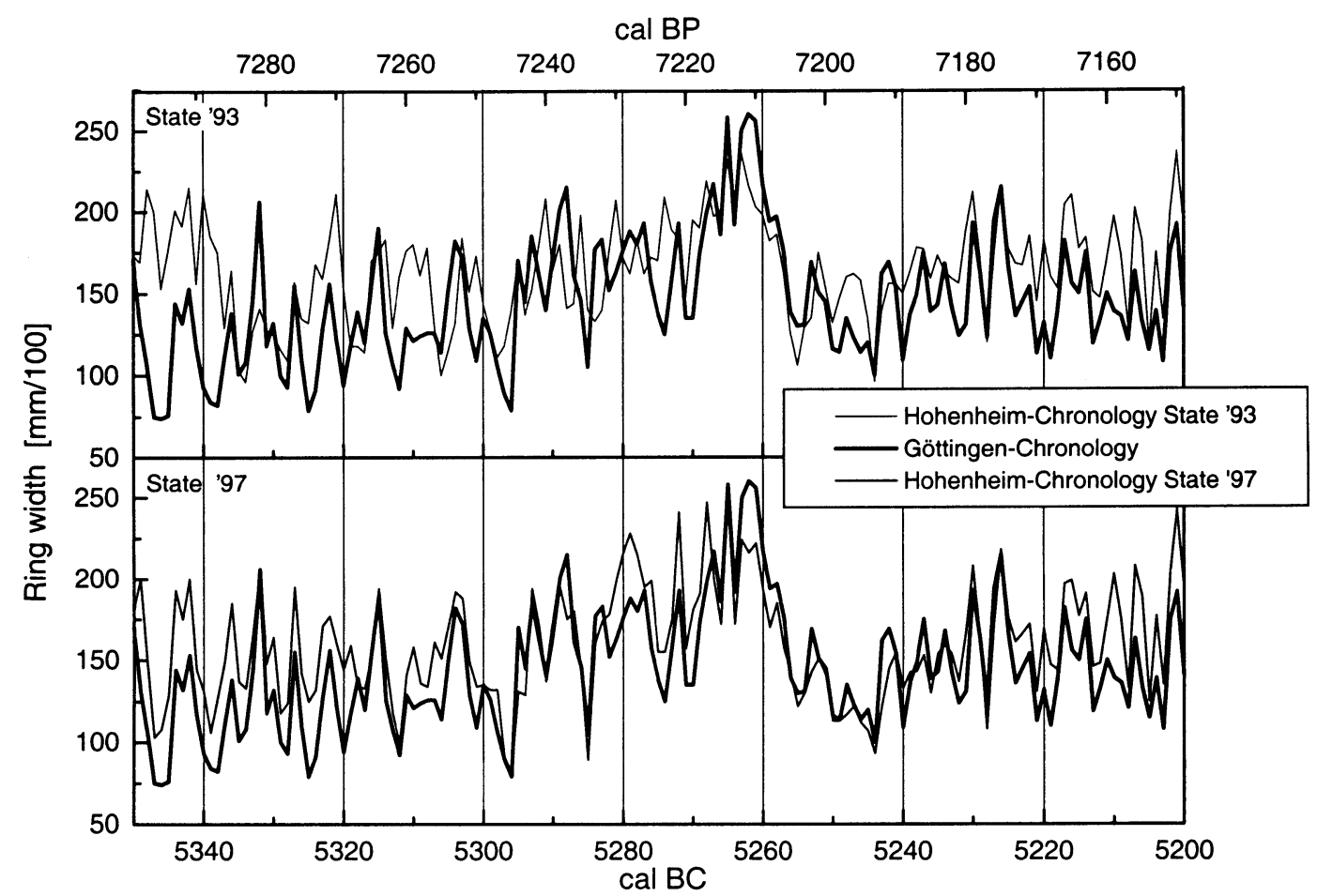

Fig. 1. Similarity of the Göttingen and Hohenheim chronologies in 1993 (State '93) and in 1997 (State '97) after the correction of the Hohenheim chronology. The statistical parameters after the correction are: Gleichläufigkeit $=77.9 \%$, $\mathrm{t}$-value $\mathrm{Baillie}=82.0$.

\section{BRIDGING THE WEAK POINT AT 7800 BC: THE 54-YR SHIFT}

All samples from the rivers Main, Regnitz and Naab (Main River chronology) were reexamined, disclosing a weak point at $7800 \mathrm{BC}$. During this period, the overlap was too short and the number of samples too low to qualify as a dendromatch. The overlap of the older "floating" part with the younger absolute oak chronology was only 35 yr long. Becker (1993) tried to improve this situation using the tree sample "Stettfeld 181", but this synchronization was not convincing and the tree was removed from the chronology. As a consequence, the pre-7792 BC section of the chronology, which had formerly been absolutely dated, was declared to be a floating 230-yr-long oak section (Kromer et al. 1996).

During the work reported here, four trees were found bridging this gap. The 210-yr-long chronology of these trees, labeled "bridging section", displays convincing similarity to the absolute part of the chronology and to the floating section, when the floating section is shifted back $54 \mathrm{yr}$ (Fig. 2). The combination of the 41-yr and the 54-yr shifts pushes the oldest samples of the previously published 


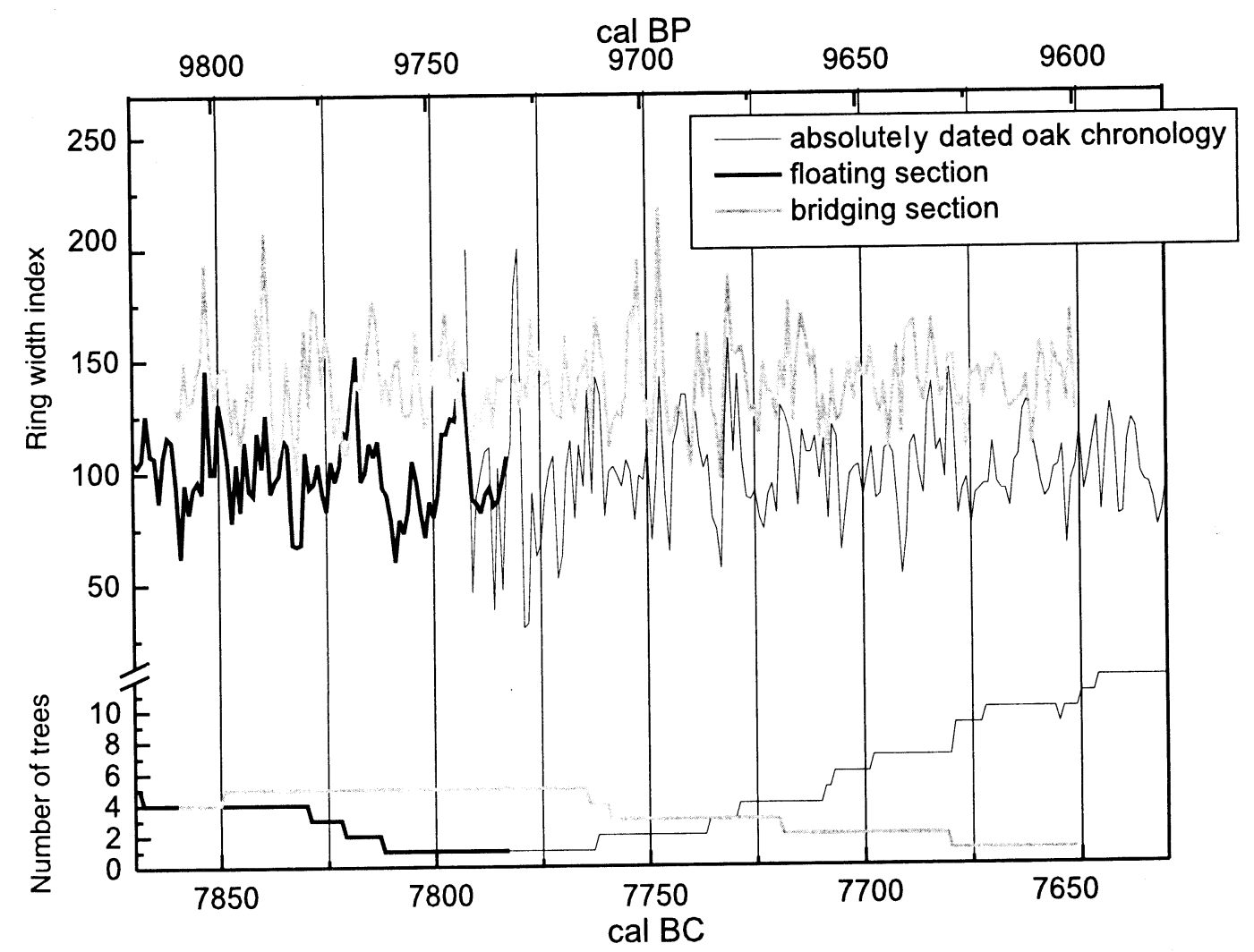

Fig. 2. Bridging the weak point at $7792 \mathrm{BC}$ with a group of four trees (bridging section). The floating section has to be shifted by 54 yr to older ages ( $95 \mathrm{yr}$ if the 41 -yr shift at $5242 \mathrm{BC}$ is included). Statistical parameters: bridging section/ floating section, Gleichläufigkeit $=72 \%$, $t$ - value $_{\text {Baillie }}=5.2$; bridging section/absolutely dated oak-chronology, Gleichläufigkeit: $68 \%$, t-value Baillie: $^{6} 6$.

oak chronology back to $8117 \mathrm{BC}$. Accordingly, the absolute oak chronology started at $8117 \mathrm{BC}$ $(10,066 \mathrm{BP})$.

With these errors recognized, the dendroscale of the Hohenheim oak chronology and consequently the ${ }^{14} \mathrm{C}$ calibration curve has to be revised. The previously published pre-5242 $\mathrm{BC}$ (pre-7191 BP) ${ }^{14} \mathrm{C}$ calibration must be shifted by $41 \mathrm{yr}$ (Kromer et al. 1996) and the pre-7792 BC (pre-9741 BP) ${ }^{14} \mathrm{C}$ calibration must be shifted by $95 \mathrm{yr}(41+54)$ to older ages. Both corrections solved hitherto existing problems in the ${ }^{14} \mathrm{C}$ calibration described in Kromer and Spurk (1998). Newly dated samples with shifts differing from the $41-\mathrm{yr}$ or $54-\mathrm{yr}$ shifts are labeled in Table 1.

TABLE 1. Numbers of the Oak Samples with Shifts Differing from the 41-yr or 54-yr Shifts

\begin{tabular}{lc}
\hline Heidelberg Lab No. & Shift to older ages \\
\hline $8510,8511,8518,8519,8524,8525,8544$ & $11 \mathrm{yr}$ \\
$8141,8140,8144,8244$ & $30 \mathrm{yr}$ \\
\hline
\end{tabular}




\section{EXTENSION OF THE OAK CHRONOLOGY BACK TO 8480 BC}

Besides those already mentioned, new trees were found that enabled an extension of the absolutely dated oak chronology back to $8480 \mathrm{BC}(10,429 \mathrm{BP})$. This was done in two steps. First, a tree was found that fitted onto the end of the absolute oak chronology and extended it back to 8239 BC $(10,188 \mathrm{BP})$. Second, a 507-yr-long floating chronology from the upper Rhine valley (Rhine chronology $9 \mathrm{~b}$ ) was linked to the absolute part of the chronology, which was established primarily with wood from the Main River. Here, key positions are occupied by three trees (Rhine chronology 9a) showing perfect ring width synchronization to the absolute part, as well as to the Rhine chronology $9 \mathrm{~b}$ (Fig. 3). As a result, the Rhine chronologies $9 \mathrm{a}$ and $9 \mathrm{~b}$ were absolutely dated, extending the absolute oak chronology back to $8480 \mathrm{BC}(10,429 \mathrm{BP})$.

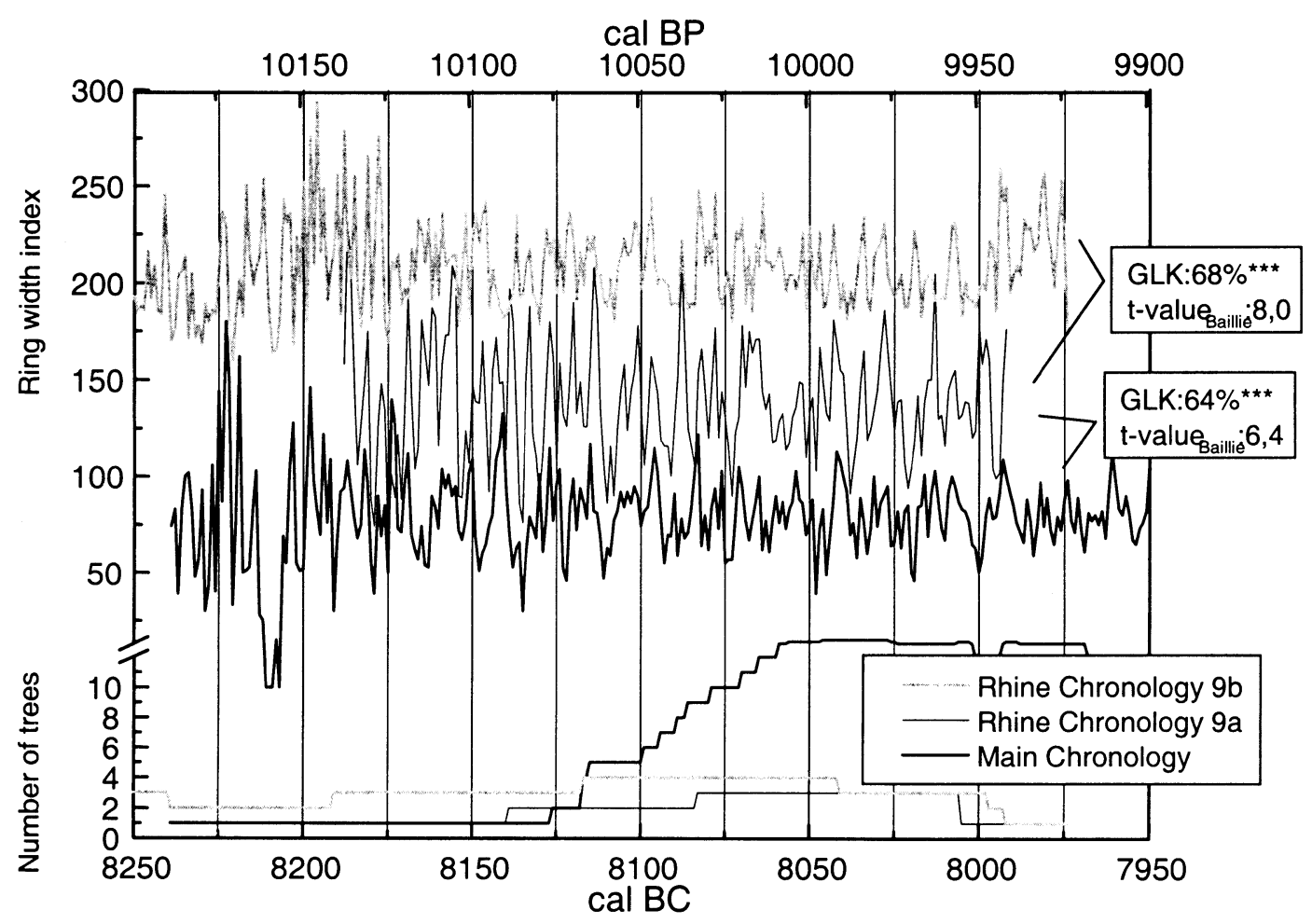

Fig. 3. Extension of the absolute oak chronology with samples from the Rhine River back to 8480 BC. A group of 3 trees (Rhine Chronology 9a) could be dated with the absolute Main chronology. This group perfectly matches the 507-yr-long floating sequence from the Rhine River (Rhine chronology 9b), thus anchoring this sequence.

Matching ${ }^{14} \mathrm{C}$ data of decadal samples from the oak extension to those of Preboreal pine resulted in a new, reliable ${ }^{14} \mathrm{C}$ link between the absolute oak chronology and the Preboreal pine chronology (see next section).

\section{LINKING THE PREBOREAL PINE CHRONOLOGY WITH THE OAK CHRONOLOGY}

In 1993 the Preboreal pine chronology (PPC) was dated by ${ }^{14} \mathrm{C}$ and tentatively linked to the oak chronology by B. Becker (1993). In 1996 this tentative link was revised by the authors. Detailed investigation into the long-term ${ }^{14} \mathrm{C}$ trend and the absence of convincing dendrochronological simi- 
larity between the two chronologies resulted in a 120-yr backward shift of the PPC, with a confidence interval of $c a . \pm 80 \mathrm{yr}$ (Björck et al. 1996).

Now that the oak chronology starts prior to the ${ }^{14} \mathrm{C}$ plateau at $8800{ }^{14} \mathrm{C}$ yr BP, it displays the sharp ${ }^{14} \mathrm{C}$ age increase between 8900 and $9200{ }^{14} \mathrm{C}$ yr BP, which can be seen in the ${ }^{14} \mathrm{C}$ calibration curve of the PPC (Kromer and Spurk 1998). By wiggle-matching the ${ }^{14} \mathrm{C}$ pattern in both chronologies, the PPC can now be linked very reliably, resulting in a PPC interval of 9922-7951 BC (11,871-9900 BP) $)^{5}$ with an uncertainty of \pm 20 yr only.

A dendrochronological linkage of the two chronologies is in preparation, but the realization is problematic due to the diversity of species originating from different rivers (the PPC is established mainly with wood from the Danube River). Even if this attempted linkage proves to be unfeasible, the Hohenheim chronologies provide a high-resolution time scale for nearly the last 12,000 years.

\section{REVISION OF THE PREBOREAL PINE CHRONOLOGY}

In 1997, when the PPC was established anew, a weak period between 9350 and $9250 \mathrm{BC}(11,299$ and 11,199 BP) became apparent, dividing the PPC into an older and a younger part. In the "weak" period the growth of the trees was very strongly disturbed, resulting in missing rings. In some trees no ring was formed for 3 to 5 consecutive years. The older part and the younger part of the PPC could be joined, however, by a tentative dendro-link. This required shifting the older part $31 \mathrm{yr}$ to older ages with respect to the 1993 stage. In terms of dendrochronology this linkage is considerably better than the earlier link, but it still has to be confirmed by additional trees (Fig. 4). The younger part of the PPC reaches from 7951 BC to $9375 \mathrm{BC}$ (9900 to 11,324 BP) and the older part from 9222 to $9922 \mathrm{BC}(11,171$ to $11,871 \mathrm{BP})$.

${ }^{14} \mathrm{C}$ measurements at Heidelberg support this tentative link. They connect the younger and the older part at exactly the position of the dendro-synchronization (Fig. 5). We therefore continue to use the PPC as a single chronology, based on the tentative link of the older and younger part (Fig. 6).

With respect to the absolute time scale of the PPC as previously published (Becker 1993; Kromer and Becker 1993), the internal revisions of the PPC result in time shifts of differing amounts, all to older ages (Table 2).

\section{TIMING OF THE YOUNGER DRYAS/PREBOREAL TRANSITION}

With the new dating of the PPC there is now evidence that the transition of the Younger Dryas to the Preboreal is reflected in the ring width of the pines (Björck et al. 1996). In the oldest part of the pine chronology the ring width is very narrow and the rings appear similar to those of pines from the alpine timberline, where summer temperature is the growth-limiting factor (Schweingruber, Briffa and Jones 1991). At 11,530 $\pm 20 \mathrm{BP}$ the ring width suddenly doubles, indicating better growing conditions. The trees growing in this manner were found at six different sites spread over $>70 \mathrm{~km}$, excluding the possibility of a local event. Better growing conditions could be caused by better water supply or higher temperatures, or a combination of both. This implies a climatic change in South Germany at $11,530 \pm 20 \mathrm{BP}$, which can be related to the Younger Dryas/Preboreal transition. In the

\footnotetext{
${ }^{5}$ At the 16th International Radiocarbon Conference in Groningen an age of 9952 to 8012 BC and a shift of 304 yr was presented. Both figures need to be corrected. In the first place, a change resulted when the PPC was newly established after the conference. Second, the incorrect labeling of some samples sent to Heidelberg entailed an incorrect shape for the ${ }^{14} \mathrm{C}$ curve of the PPC, which was used to create the linkage with the absolute oak chronology.
} 


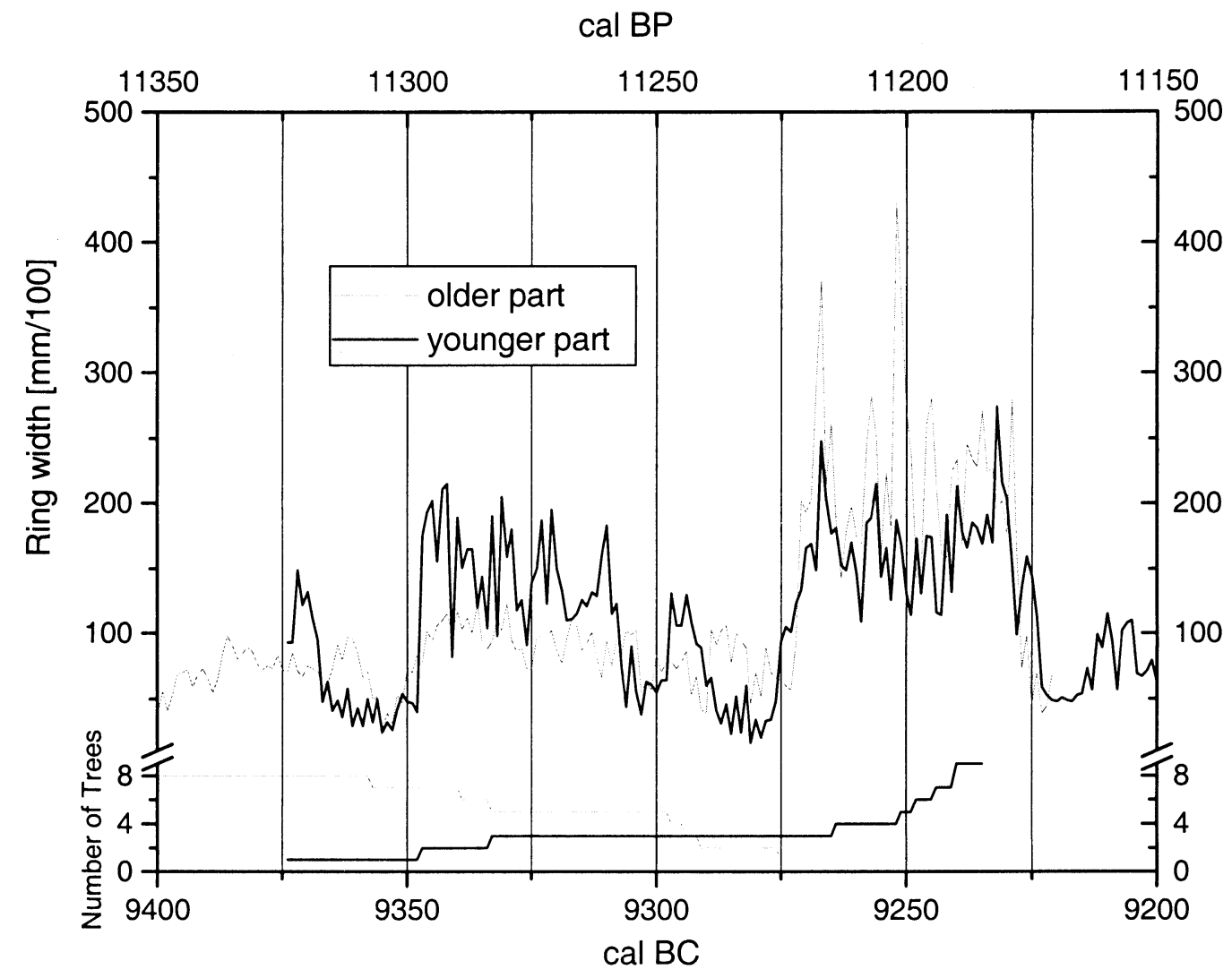

Fig. 4. Tentative ring-width linkage of the younger and the older part of the PPC. (Gleichläufigkeit $=62 \%$, $t$-value ${ }_{B a i l l i e}$ =3.0). This linkage needs to be confirmed by additional trees. The growth of the trees is disturbed and rings are missing, complicating the linkage of both parts. The synchronization is supported by the ${ }^{14} \mathrm{C}$ wiggle-matching.

Greenland ice cores the rapid transition of the $\delta^{18} \mathrm{O}$ data took place at $11,550 \pm 90 \mathrm{BP}$ (GRIP: Johnsen et al. 1992) and 11,640 \pm 240 BP (GISP2: Taylor et al. 1993), respectively. At 11,440 \pm 120 BP there is an abrupt increase of $\delta^{18} \mathrm{O}$ in the Lake Gościąż data record, combined with changes in terrestrial and lacustrine vegetation (Goslar, Arnold and Pazdur 1995). Furthermore, when the $\delta^{18} \mathrm{O}$ record of the Lake Gościąż is related to the PPC by ${ }^{14} \mathrm{C}$ wiggle-matching, the increase of the $\delta^{18} \mathrm{O}$ and the increase in ring width takes place at the same time (T. Goslar, personal communication). Records from Europe now match well, and taking into account the uncertainty of the time scales, it is possible that the Younger Dryas/Preboreal transition in Greenland and Europe occurred simultaneously.

\section{CONCLUSION}

The comparison of the two long South German oak chronologies entailed a revision of the pre$5242 \mathrm{BC}$ part of the Hohenheim chronologies but also confirmed the time scale back to $7792 \mathrm{BC}$. The reexamination of the pre-5100 $\mathrm{BC}$ samples and the reestablishing of the Hohenheim oak chronology resulted, moreover, in an extension of the oak chronology back to $8480 \mathrm{BC}$. This enabled a ${ }^{14} \mathrm{C}$ linkage of the Preboreal pine chronology with an uncertainty of $\pm 20 \mathrm{yr}$, whereby the pine chronology was shifted to older ages. The PPC was established anew resulting in a younger and an older part, 
TABLE 2. Ages and the corresponding shifts of the PPC samples. "cal BC 1993" refers to the age from the previous publications (Becker 1993; Kromer and Becker 1993), "cal BC 1998" to that from 1998.

\begin{tabular}{|c|c|c|c|c|c|c|c|}
\hline $\begin{array}{l}\text { Lab } \\
\text { code } \\
\text { (Hd-) } \\
\end{array}$ & $\begin{array}{c}\text { cal BC } \\
1993 \\
\end{array}$ & Shift & $\begin{array}{c}\text { cal BC } \\
1998 \\
\end{array}$ & $\begin{array}{l}\text { Lab } \\
\text { code } \\
\text { (Hd-) }\end{array}$ & $\begin{array}{c}\text { cal BC } \\
1993 \\
\end{array}$ & Shift & $\begin{array}{c}\text { cal BC } \\
1998 \\
\end{array}$ \\
\hline 13511 & -9439 & -231 & -9670 & 9005 & -8728 & -200 & -8928 \\
\hline & -9429 & -231 & -9660 & 8826 & -8723 & -200 & -8923 \\
\hline 13525 & -9409 & -231 & -9640 & & -8708 & -200 & -8908 \\
\hline 13526 & -9389 & -231 & -9620 & 9865 & -8855 & -42 & -8897 \\
\hline & -9385 & -221 & -9606 & 8836 & -8693 & -200 & -8893 \\
\hline 10568 & -9355 & -221 & -9576 & 8867 & -8678 & -200 & -8878 \\
\hline & -9323 & -231 & -9554 & 8868 & -8663 & -200 & -8863 \\
\hline & -9309 & -231 & -9540 & & -8648 & -200 & -8848 \\
\hline & -9304 & -231 & -9535 & 8877 & -8633 & -205 & -8838 \\
\hline & -9289 & -23 & -9520 & 8889 & -8618 & -200 & -8818 \\
\hline & -9279 & -231 & -9510 & 8890 & -8603 & -205 & -8808 \\
\hline & -9254 & -2 & 85 & 8911 & -8573 & -200 & -8773 \\
\hline & -9229 & -231 & -9460 & 8904 & -8558 & -200 & -8758 \\
\hline & -9219 & -2 & -9450 & 8905 & -8543 & -200 & -8743 \\
\hline & -9199 & -231 & -9430 & 8977 & 8525 & -203 & -8728 \\
\hline & -9194 & -231 & -9425 & 8957 & -8508 & -200 & -8708 \\
\hline & -9184 & -231 & -9415 & 8 & -8495 & -200 & -8695 \\
\hline 12 & -9174 & -231 & -9405 & & -8473 & -200 & -8673 \\
\hline & -9159 & -231 & -9390 & 9026 & -8468 & -200 & -8668 \\
\hline 9097 & -9 & -214 & -9373 & & -8458 & -200 & -8658 \\
\hline & -9144 & -214 & -9358 & 9007 & -8453 & -200 & -8653 \\
\hline 9118 & -9127 & -214 & -9341 & 8 & -8435 & -200 & -8635 \\
\hline 9119 & -9107 & -214 & -9321 & 9064 & -8433 & -200 & -8633 \\
\hline 9126 & -9087 & -214 & -9301 & & -8418 & -200 & -8618 \\
\hline 9127 & -9067 & -214 & -9281 & 9160 & -8403 & -200 & -8603 \\
\hline 9134 & -9047 & -211 & -9258 & & -8388 & -200 & -8588 \\
\hline 9810 & -9042 & -206 & 48 & 191 & -8373 & -200 & -8573 \\
\hline 99 & -9038 & -20 & 243 & ? & -8358 & -200 & -8558 \\
\hline & -9022 & -214 & 36 & 99 & -8345 & -200 & -8545 \\
\hline 9811 & -9026 & -206 & 32 & 10001 & -8335 & -200 & -8535 \\
\hline 9970 & -9015 & -206 & 21 & 10 & -8315 & -200 & -8515 \\
\hline 915 & -9002 & -214 & 16 & & & -200 & -8505 \\
\hline & -9007 & -2 & 13 & 3 & -8295 & -200 & -8495 \\
\hline 9808 & -8991 & -205 & & & 0 & -201 & -8486 \\
\hline 13009 & -8989 & -2 & -9194 & 4 & 8275 & -201 & -8476 \\
\hline 983 & -8983 & & & & 20 & -201 & -8456 \\
\hline 130 & -8974 & -205 & -9179 & 10 & -8235 & -201 & -8436 \\
\hline 98 & -8972 & -20 & & & & -201 & -8416 \\
\hline 13059 & -8954 & -20 & -9159 & 10 & -8195 & -201 & -8396 \\
\hline 130 & -8936 & -20 & & & -8175 & -201 & -8376 \\
\hline 130 & -886 & -200 & -9066 & 10091 & -8145 & -201 & -8346 \\
\hline 130 & -8844 & -200 & & & & -201 & -8336 \\
\hline 13016 & -8829 & -200 & -9029 & & -8115 & -201 & -8316 \\
\hline & -8809 & -200 & -9009 & & & -201 & -8296 \\
\hline & -8794 & -200 & -8994 & & -8085 & -200 & -8285 \\
\hline 142 & -878 & -200 & & & -8075 & -20 & -8275 \\
\hline 98 & -8925 & -42 & -8967 & 10338 & -8065 & -20 & -8265 \\
\hline 98 & -8911 & -42 & -8953 & 9769 & -7833 & -243 & -8076 \\
\hline 9864 & -8891 & -4 & -8933 & -- & - & -- & -- \\
\hline
\end{tabular}




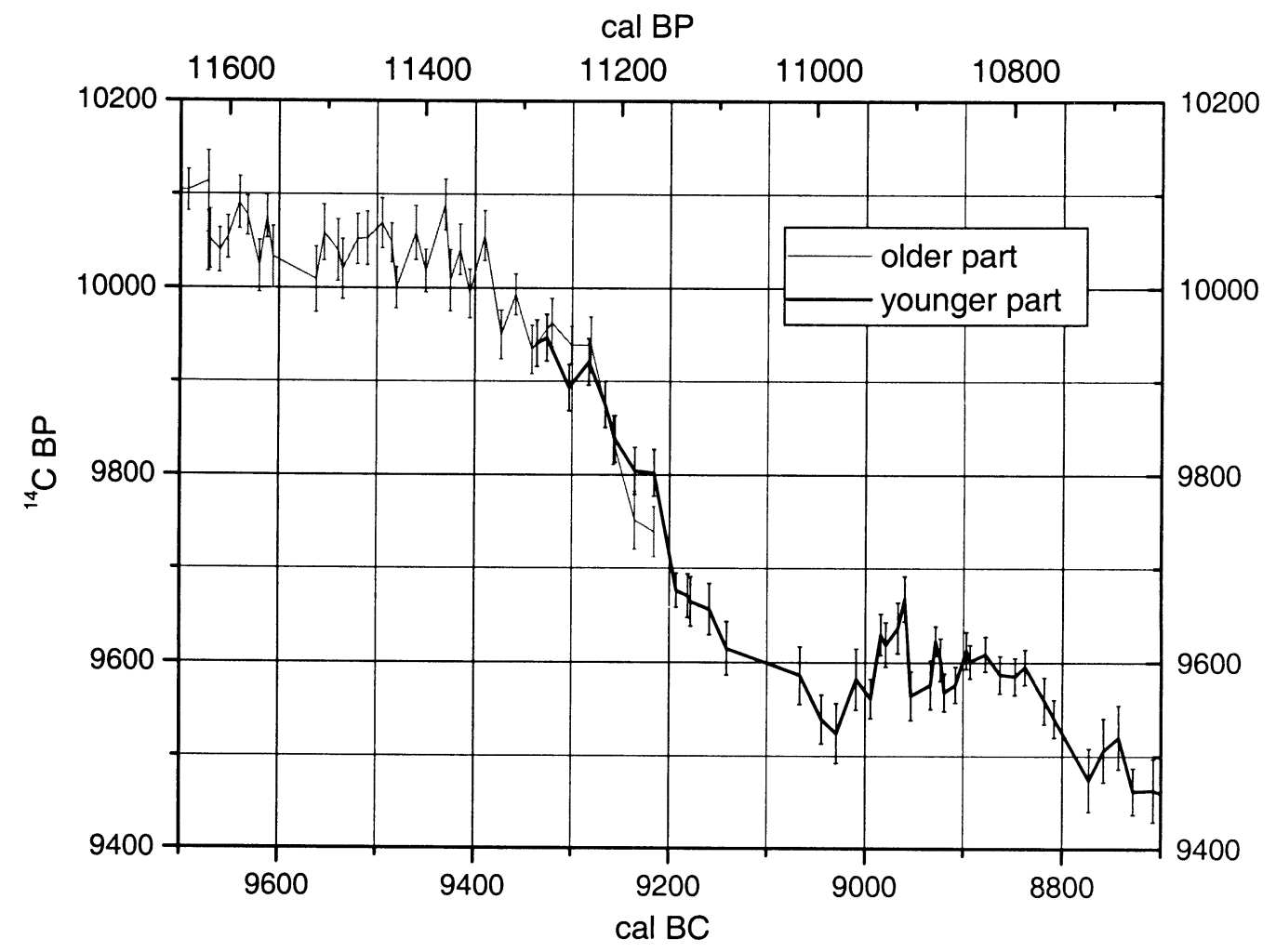

Fig. $5 .{ }^{14} \mathrm{C}$ measurements confirm the tentative linkage of the older and younger part of the PPC

which were tentatively linked together. As a consequence, the previously published ${ }^{14} \mathrm{C}$ calibration curve has to be revised prior to $5242 \mathrm{BC}$ according to the corrections of the Hohenheim chronologies.

With these revisions, the Hohenheim chronologies provide a high-resolution time scale for nearly the last 12,000 years. The new situation has enabled the resolution of apparent discrepancies with other long data records involving the timing of the Younger Dryas/Preboreal transition.

\section{ACKNOWLEDGMENTS}

This paper is dedicated to Bernd Becker, who was sadly unable to complete his work during his lifetime. The dendrochronological research was supported by the European Commission (ENV4CT95-0127-PL951087) and the BMBF (Bundesministerium für Bildung, Wissenschaft, Forschung und Technologie, 07VKV/01A-21178.3/3). We also thank Sandra Hauser, Sabine Schmidt, Claudia Schuster and Silke Wurst for precise ring-width measurements. 


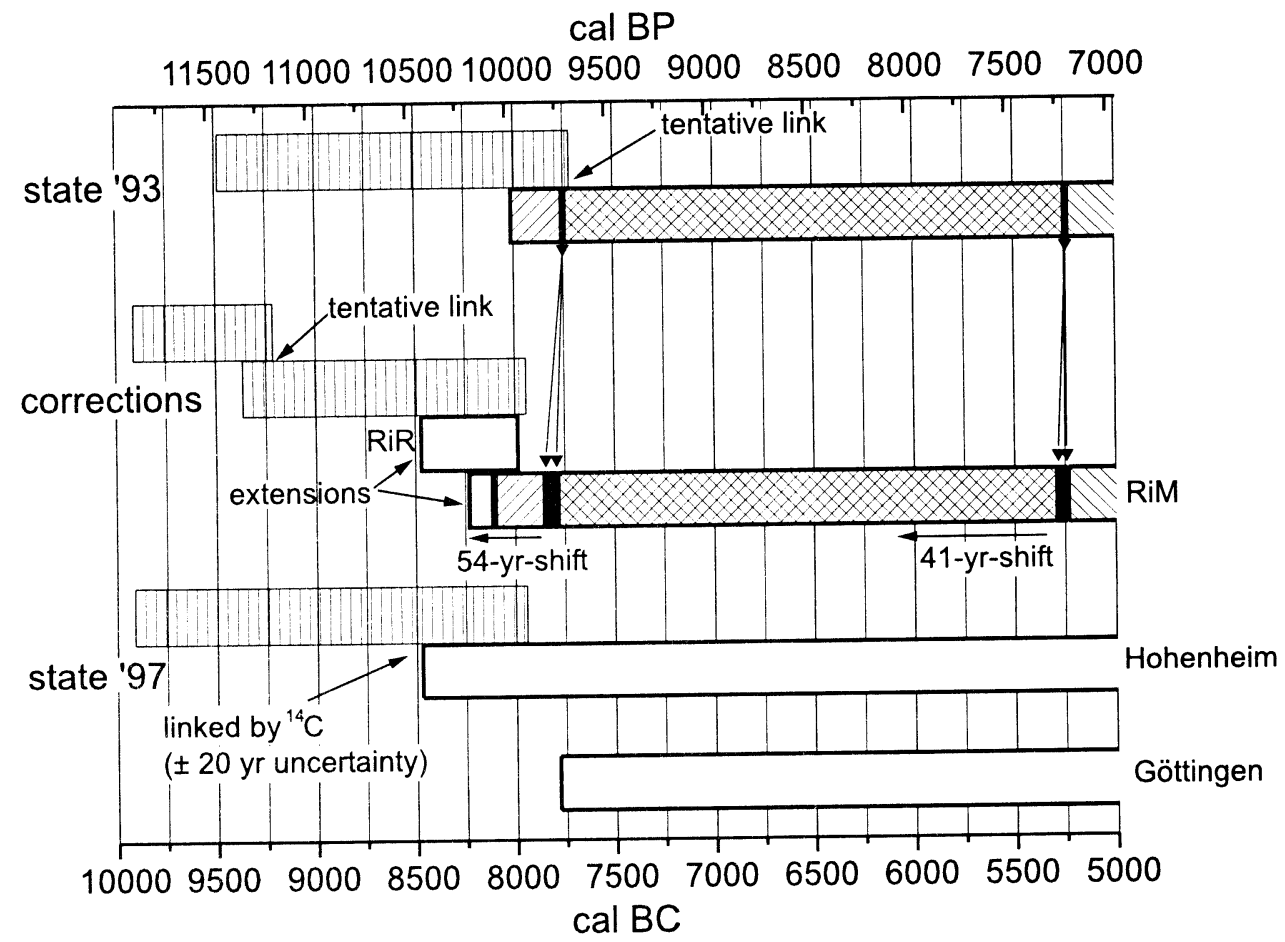

Fig. 6. Range of the Hohenheim chronologies before (state '93) and after (state '97) the revisions and extensions (thicklined rectangles with various fill patterns $=$ oaks, thin-lined rectangles with vertical fill $=$ pines). The revisions of the oak chronology are shown in three segments. The youngest segment is shifted by $41 \mathrm{yr}$ (crosshatched fill); the middle one by 54 yr (diagonal fill). As a result of these shifts the earliest segment is moved by 95 yr (diagonal fill). The chronologies from the Main River (RiM) and Rhine River (RiR) are synchronized, extending the oak chronology back to 8480 BC. The pine chronology is linked to the absolutely dated oak chronology by ${ }^{14} \mathrm{C}$ measurements with an uncertainty of \pm 20 yr. The PPC is divided into an older and a younger part that are synchronized tentatively. The Göttingen chronology and the Hohenheim chronology are mutually corroborative back to $7736 \mathrm{BC}$.

\section{REFERENCES}

Becker, B. 1993 An 11,000-year German oak and pine dendrochronology for radiocarbon calibration. In Stuiver, M., Long, A. and Kra, R. S., eds., Calibration 1993. Radiocarbon 35(1): 201-213.

Becker, B., Kromer, B. and Trimborn, P. 1991 A stableisotope tree-ring timescale of the Late Glacial/Holocene boundary. Nature 353: 647-649.

Björck, S., Kromer, B., Johnsen, S., Bennike, O., Hammarlund, D., Lemdahl, G., Possnert, G., Rasmussen, T. L., Wohlfarth, B., Hammer, C. U. and Spurk, M. 1996 Synchronized terrestrial-atmospheric Deglacial records around the North Atlantic. Science 274: 11551160.

Goslar, T., Arnold, M., Bard, E., Kuc, T., Pazdur, M. F., Ralska-Jasiewiczowa, M., Różanski, K., Tisnerat, N., Walanus, A., Wicik, B. and Więckowski, K. 1995 High concentration of atmospheric ${ }^{14} \mathrm{C}$ during the Younger Dryas cold episode. Nature 377: 414-417.
Goslar, T., Arnold, M. and Pazdur, M. F. 1995 The Younger Dryas cold event - was it synchronous over the North Atlantic region? Radiocarbon 37(1): 63-70.

Johnsen, S. J., Clausen, H. B., Dansgaard, W., Fuhrer, K., Gundestrup, N., Hammer, C. U., Iversen, P., Jouzel, J., Stauffer, B. and Steffensen, J. P. 1992 Irregular glacial interstadials recorded in a new Greenland ice core. Nature 359: 311-313.

Kromer, B., Ambers, J., Baillie, M. G. L., Damon, P. E., Hessheimer, V., Hofmann, J., Jöris, O., Levin, I., Manning, S. W., McCormac, F. G., van der Plicht, J., Spurk, M., Stuiver, M. and Weninger, B. 1996 Report: Summary of the workshop "Aspects of High-Precision Radiocarbon Calibration". Radiocarbon 38(3): 607-610.

Kromer, B. and Becker, B. 1993 German oak and pine ${ }^{14} \mathrm{C}$ calibration, $7200-9439$ BC. In Stuiver, M., Long, A. and Kra, R. S., eds., Calibration 1993. Radiocarbon 
35(1): 125-135.

Kromer, B. and Spurk, M. 1998 Revision and tentative extension of the tree-ring based ${ }^{14} \mathrm{C}$ calibration, 9200 11,855 cal BP. Radiocarbon, this issue.

Leuschner, H.-H. 1992 Subfossil Trees. In Tree Rings and Environment: Proceedings of the International Dendrochronological Symposium. Lundqua Report 34: 193-197.

Schweingruber, F. H., Briffa, K. R. and Jones, P. D. 1991 Yearly maps of summer temperatures in Western Europe from A.D. 1750 to 1975 and western north America from 1600 to 1982. Vegetatio 92: 5-71.

Stuiver, M. and Becker, B. 1993 High-precision decadal calibration of the radiocarbon time scale, AD 19506000 BC. In Stuiver, M., Long, A. and Kra, R. S., eds., Calibration 1993. Radiocarbon 35(1): 35-65.

Taylor, K. C., Hammer, C. U., Alley, R. B., Clausen, H. B., Dahl-Jensen, D., Gow, A. J., Gundestrup, N. S., Kipfstuhl, J., Moore, J. C. and Waddington, E. D. 1993 Electrical conductivity measurements from the GISP2 and GRIP Greenland ice cores. Nature 366: 549-552.

Vogel, J. C., Fuls, A., Visser, E. and Becker, B. 1993 Pretoria calibration curve for short-lived samples, 19303350 BC. In Stuiver, M., Long, A. and Kra, R. S., eds., Calibration 1993. Radiocarbon 35(1): 73-86. 